\title{
Planktonic algae as bioindicators of water quality in Pagbanganan River, Baybay City, Leyte
}

\author{
Eunice Kenee L. Seriño ${ }^{1 *}$ and Beatriz S. Belonias
}

\begin{abstract}
Submitted: 11 September 2019 | Accepted: 9 June 2020

Biological monitoring is a valuable method used in conservation studies to protect and preserve the biological integrity of natural ecosystems. This study was conducted to assess the water quality of the Pagbanganan River using planktonic algae as bioindicators of organic pollution. Horizontal tows were made in three selected stations (upstream, midstream \& downstream) using a Wisconsin plankton net with $80 \mu \mathrm{m}$ mesh size. Collected samples were preserved with Lugol's solution and $70 \%$ ethyl alcohol. Identified phytoplankton genera were analyzed using Palmer's Pollution Index. Out of the 20 pollution indicator genera identified by Palmer (1969), 10 were present in Pagbanganan River, namely; Ankistrodesmus, Closterium, Cyclotella, Gomphonema, Melosira, Navicula, Nitzschia, Oscillatoria, Stigeoclonium, and Synedra. Four of these were among the most abundant algae in the river. Mean Palmer's Pollution Index Scores indicate that there is "less" organic pollution existing in the river. Results imply that the river is still relatively safe for general household use, but effective conservation measures should be done to preserve the integrity of the river ecosystem.
\end{abstract}

Keywords: planktonic algae, bioindicators, water quality, Palmer's pollution index

\section{INTRODUCTION}

In recent years, growing social concern about environmental quality is observed both on a global and local scale due to the more convincing evidence that environmental pollution results in degradation of ecosystems (Gadzała-Kopciuch et al 2004). One of the most pressing environmental concerns today is the declining availability of safe, clean water due to organic pollution. Chemical analyses of water provide a good indication of the chemical quality of the aquatic systems but do not necessarily reflect the ecological state of the system since some ecological factors

'Department of Biological Sciences, Visayas State University, Baybay City, Leyte

*Corresponding Author. Address: Department of Biological Sciences, Visayas State University, Baybay City, Leyte; Email:eklserino@vsu.edu.ph

DOI: $10.32945 /$ atr 4224.2020 
are not integrated (Karr et al 2000). However, biological assessment is a functional alternative for assessing the ecological quality of freshwater ecosystems since biological communities integrate the environmental effects of water chemistry, in addition to the physical and geomorphological characteristics of rivers and lakes (Stevenson \& Pan 1999).

Biological monitoring is a valuable method used in conservation studies to protect and preserve the biological integrity of natural ecosystems (Kumari et al 2007). Moreover, Verma (2002) emphasized that bioindicators of pollutants are useful in predicting the level and degree of pollutants present in an ecosystem before the damaging effects of pollutants become more apparent. The use of aquatic biota to detect pollution in water is an option that has recently become attractive to some researchers (Hassan et al 2008). Beaugrand et al (2000) reported that planktonic algae have been used as bioindicators to monitor aquatic ecosystems and their integrity. Since planktonic algae are considered to be at the bottom of the food chain in aquatic ecosystems, alterations to their numbers and diversity will affect the entire food web.

The Pagbanganan watershed, which covers an area of about 16,762ha, is classified as a fifth-order basin with 117 streams of all orders (Alvarado 2005). The watershed drains into its tributaries, most especially into the Pagbanganan River, which is one of the major river systems in Baybay City. It is also one of the twelve major river systems on the island of Leyte that are considered flood-prone based on recorded flooding history. In the Baybay City area, this river is very important to some residents for their daily activities such as doing laundry, swimming, fishing, and for the wallowing of their farm animals.

Only a few studies on freshwater planktonic algae have been conducted in the Pagbanganan River. Labonite and Belonias (2013) studied the community structure of planktonic algae in the Pagbanganan River. This current study is related to Labonite and Belonias (2013) because it used the same data set. However, this paper focused more on using planktonic algae as bioindicators to assess the water quality of the river, which was not covered by the previous study. Assessing the river's water quality could provide useful information for the formulation of measures on how to protect and conserve the river ecosystem. Moreover, this study would provide important knowledge about these microscopic organisms as bioindicators of environmental perturbations in lotic ecosystems.

The study attempts to identify the phytoplankton genera that are indicators of organic pollution and determine the degree of organic pollution in the river by using Palmer's Pollution Index in the three selected sites along the Pagbanganan River, Baybay City, Leyte.

\section{MATERIALS AND METHODS}

\section{Establishment of the Sampling Stations}

A reconnaissance survey was done to identify the three sampling stations along the Pagbanganan River, Baybay City, Leyte. The stations were established in the upstream (Site 1), midstream (Site 2), and downstream (Site 3) parts of the river based on elevation. Site 1 was located in Brgy. Kantagnos, while sites 2 and 3 were located in Brgy. Igang, Baybay City. Geographic coordinates were taken from each 
Planktonic algae as bioindicators of water quality in Pagbanganan River

station using a handheld Global Positioning System (GPS) instrument. The selected stations were mapped using the integration of GPS and the Arc-View Geographic Information System (GIS) at the GIS Laboratory, Eco-FARMI Building, Visayas State University, Visca, Baybay City, Leyte (Figure 1).
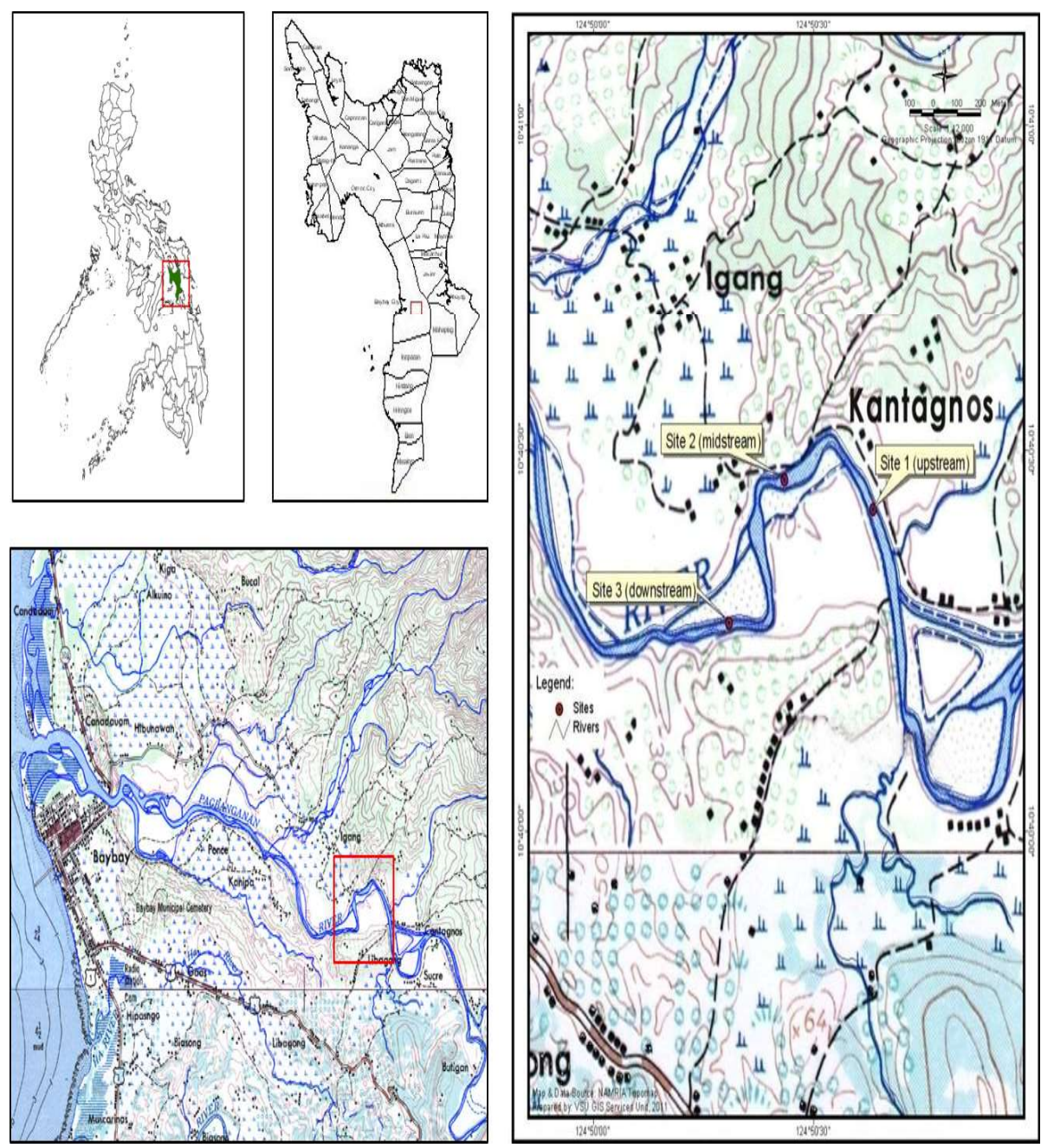

Figure 1. Map of Pagbanganan River, Baybay City, Leyte showing the three sampling sites

\section{Phytoplankton Collection, Examination, and Identification}

A sampling of planktonic algae was done once a month from April to September 2011-April to June for the low rainfall months, and July to September for the high rainfall months. The collection of samples was between 8:00 to 11:00 in the morning. This is an estimated time for algae to move up in the water column towards the sunlight for photosynthesis. While walking, three horizontal tows were made along a $30 \mathrm{~m}$ distance parallel to the river in each sampling station using a 
Wisconsin plankton net having a mesh size of $80 \mu \mathrm{m}$. Collected phytoplankton samples were placed in properly labeled plastic containers and were preserved in Lugol's solution and $70 \%$ ethyl alcohol.

Phytoplankton samples were examined under the Ken-A-Vision electric compound microscope. Counts were made using a Sedgwick-Rafter counting chamber, which is one of the standard methods for counting algal cells in samples (Suthers et al 2009). Three $1 \mathrm{~mL}$ aliquots from each sample from each tow per station were examined for the identification and enumeration of the phytoplankton genera. These were counted and identified down to the genus level. The taxonomic works of Bellinger and Sigee (2010), Belcher and Swale (1979), and Palmer (1977) were used as main references for the initial identification of the phytoplankton genera. Digital images from the Protist Information Server (http://protist.i.hosei.ac.jp.html) were likewise used in identification.

\section{Assessment of Water Quality Using Planktonic Algae}

The phytoplankton genera identified in the three sampling stations were compared with the list of pollution-tolerant genera listed by Palmer (1969) (Table 1). In Palmer's Pollution Index, a minimum of 50 individual cells of a particular genus is required for its corresponding index.

Table 1. Pollution-tolerant algal genera listed by Palmer (1969)

\begin{tabular}{lclc}
\hline Genus & Index Score & Genus & Index Score \\
\hline Anacystis & 1 & Micractinium & 1 \\
Ankistrodesmus & 2 & Navicula & 3 \\
Chlamydomonas & 4 & Nitzschia & 3 \\
Chlorella & 3 & Oscillatoria & 5 \\
Closterium & 1 & Pandorina & 1 \\
Cyclotella & 1 & Phacus & 2 \\
Euglena & 5 & Phormidium & 1 \\
Gomphonema & 1 & Scenedesmus & 4 \\
Lepocinclis & 1 & Stigeoclonium & 2 \\
Melosira & 1 & Synedra & 2
\end{tabular}

Note: CM Palmer reviewed 269 reports of 165 authors as a basis for the development of the pollution index. To combine the results of the various works, a score was given for each alga reported by an author as tolerating high organic enrichment, the larger figure being reserved for the algae that an author emphasized as particularly significant (Palmer 1969).

After obtaining the scores of all the genera observed in each site, the Total Pollution Index Score (Table 2) was obtained. A score lower than 15 means the body of water has less organic pollution; 15-19 indicates probable organic pollution, and 20 or more signify high organic pollution in the area. 
Planktonic algae as bioindicators of water quality in Pagbanganan River

Table 2. Degree of pollution based on the pollution index scores (Palmer 1969)

\begin{tabular}{ll}
\hline Pollution Index Score & \multicolumn{1}{c}{ Description } \\
\hline 20 or more & high organic pollution \\
$15-19$ & probable organic pollution \\
lower than 15 & less organic pollution \\
\hline
\end{tabular}

\section{RESULTS AND DISCUSSION}

A total of 39 phytoplankton genera belonging to four divisions were recorded in Pagbanganan River, Baybay City, Leyte (Table 3). Out of the 39 genera, 21 belong to Division Bacillariophyta; 12 belong to Division Chlorophyta; four belong to Division Cyanophyta, and two belong to Division Charophyta. However, a plankton study by Galinato and Evangelio (2016) in Banahao-Palhi River, Baybay City, Leyte recorded 58 phytoplankton genera. Diatoms dominated the Pagbanganan River, while the Banahao-Palhi River was dominated by both diatoms and green algae.

According to Palmer (1969), organic pollution tends to influence the algal flora more than many other factors in the aquatic environment. Palmer carried out extensive research to assess the tolerance of algal species to organic pollution and designed an organic pollution index for rating water quality. Table 3 also shows the pollution index values of the pollution-tolerant algal genera found in the Pagbanganan River within the six-month study period.

Out of the 20 algal genera listed by Palmer (1969) as indicators of organic water pollution, ten genera were documented in Pagbanganan River, namely; Ankistrodesmus, Closterium, Cyclotella, Gomphonema, Melosira, Navicula, Nitzschia, Oscillatoria, Stigeoclonium, and Synedra. However, most of the indicator genera encountered had less than 50 individuals per $\mathrm{mL}$; thus, no index scores were given. Interestingly, a high density of individuals was observed in most diatom indicator genera. Labonite and Belonias (2013) reported that Navicula, Nitzschia, Synedra, and Melosira were the top four most abundant genera in Pagbanganan River.

In Banahao-Palhi River, Galinato and Evangelio (2016) encountered nine (9) pollution indicator genera, namely; Ankistrodesmus, Closterium, Chlorella, Cyclotella, Gomphonema, Navicula, Nitzschia, Scenedesmus, and Synedra. It is good to note that the composition of indicator genera is more or less the same in both rivers, which could imply that both sites may have similar habitat conditions for these genera to thrive. However, Palmer's Pollution Index score was not determined in the Banahao-Palhi River study. In Pagbanganan River, Palmer's Pollution Index scores were high in April (10) and May (10), while the lowest score was observed in September (6) based on the mean density of planktonic algae across sampling months. 
Seriño \& Belonias

Table 3. Planktonic algal taxa and Palmer's Index Scores in Pagbanganan River, Baybay City, Leyte

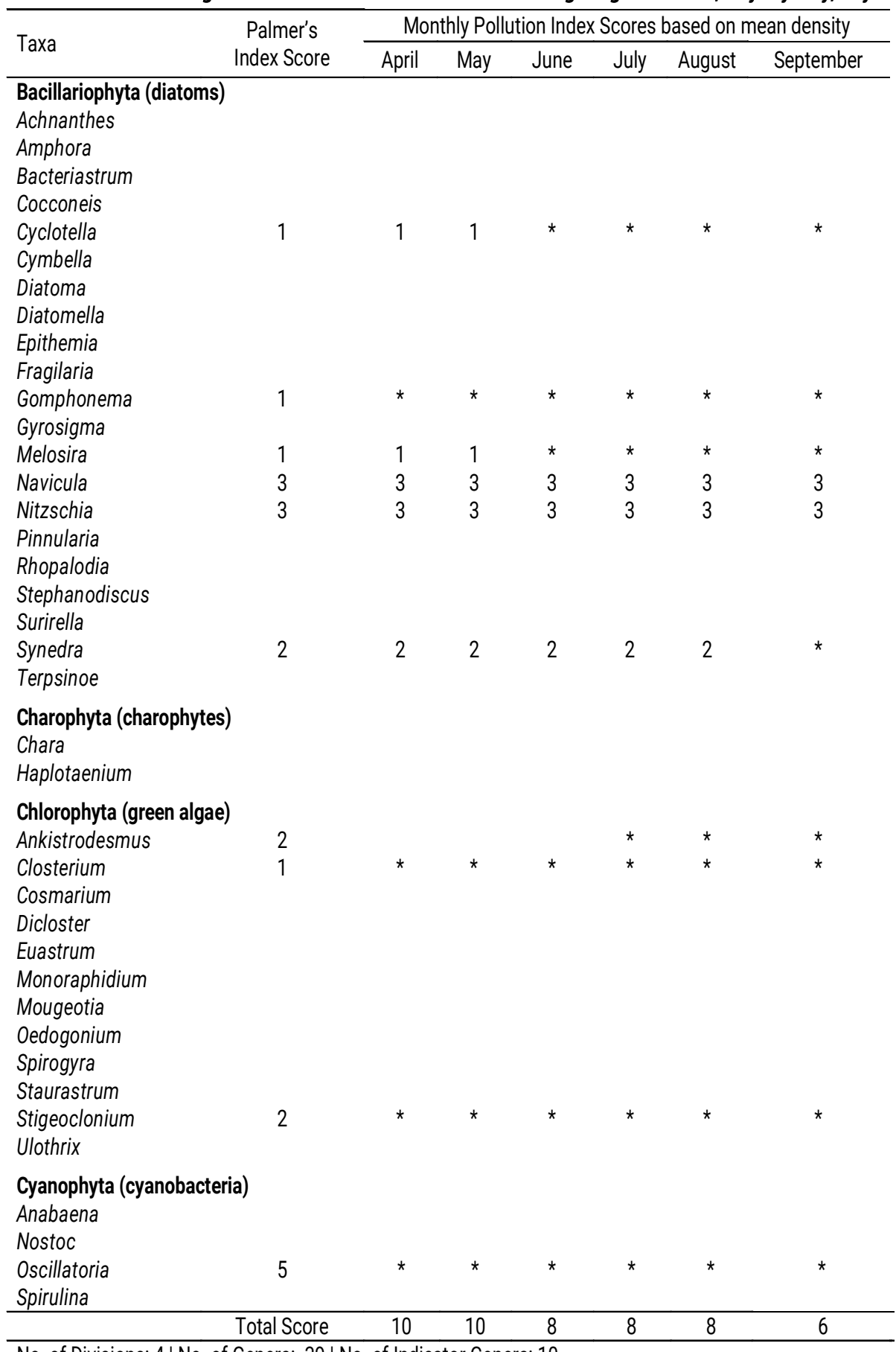

No. of Divisions: 4 | No. of Genera: 39 | No. of Indicator Genera: 10

Note: * Indicator genus present but less than 50 individuals per $\mathrm{mL}$; thus, no index score was assigned. 


\section{Planktonic algae as bioindicators of water quality in Pagbanganan River}

Figure 2 shows the Palmer's Pollution Index scores across sampling sites per month in the Pagbanganan River. The highest score was in April, particularly in the midstream (10) portion and in May in the upstream (10). Low scores were observed in downstream (3) and upstream (3) sites in September and lowest in the upstream (2) portion in July. Overall, index scores fall below 15, which indicates that there is "less organic pollution" in the Pagbanganan River.

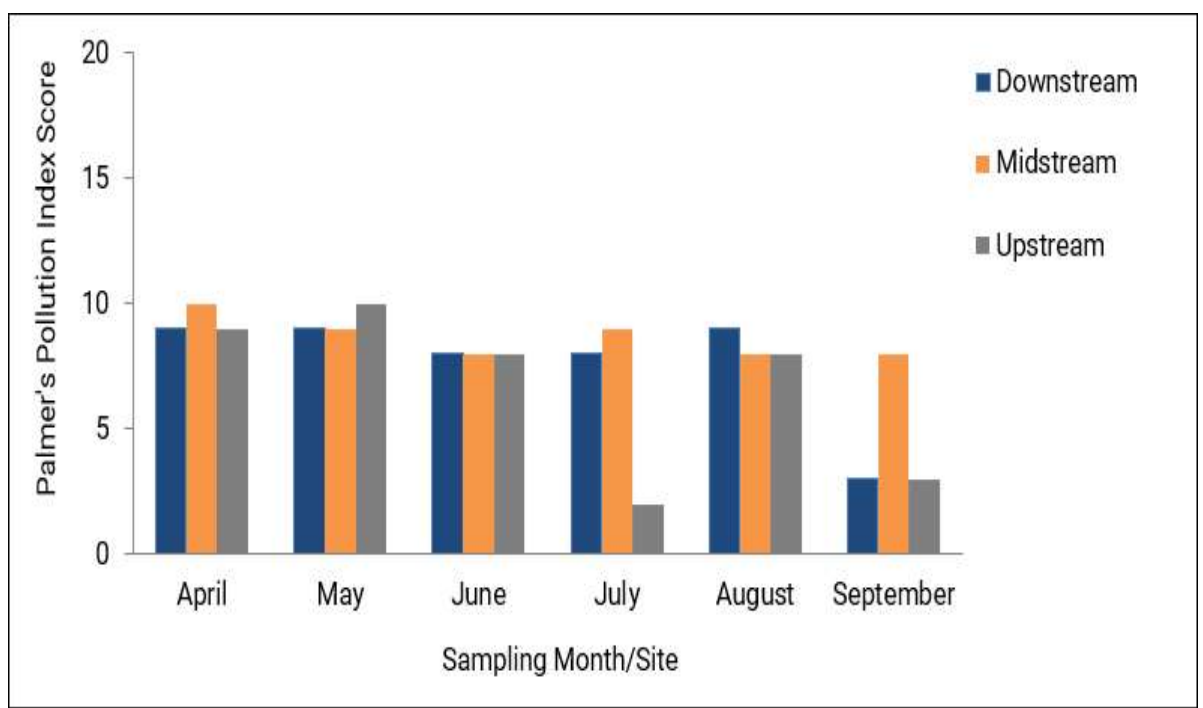

Figure 2. Mean Palmer's Pollution Index scores across sites per month in Pagbanganan River, Baybay City, Leyte

Palmer's Pollution Index was a substantial tool to show the probability of organic pollution in the three sampling sites in the Pagbanganan River. It provides a descriptive approach in determining organic pollution by using indicator algae even at the genus level. There have been several studies that used Palmer's pollution index as a basis for determining water quality in different freshwater bodies. Salem et al (2017) assessed the surface water quality in irrigation canals and drainage in the middle Nile Delta, and they found out that Palmer's index of genera was more helpful than that of the species in the case of drainage water. Jose and Kumar (2011) evaluated the water quality of temple ponds in Kerala, India, and computed that the index scores ranged from 14-19, which suggested that all the ponds showed probable high levels of organic pollution.

In the Philippines, Palmer's algal genus pollution index was also used as one of the indicators in developing a river health index in Ylang-ylang River, Cavite (Martinez 2018). In Batangas, the index was also used to assess the water quality in Dao River, and it was concluded that phytoplankton biomonitoring complements the physicochemical analysis in checking the pollution level of water bodies (Lacdan et al 2014).

Organic pollution in water occurs when an excess of organic matter enters the aquatic environment. According to Palmer (1977), one of the principal reasons for 
the importance of algae is their ability to give rise to large quantities of organic matter in the water, making them good bioindicators for an ecosystem's health. Belcher and Swale (1979) mentioned that in most rivers, nitrates and phosphates derived from agricultural run-off, manure, and sewage are responsible for algal growth in freshwater bodies. Labonite and Belonias (2013) noted that temperature, $\mathrm{pH}$, dissolved oxygen and nitrate levels in Pagbanganan River were within safe limits. However, phosphate level $\left(0.258-1.037 \mathrm{mg} \mathrm{L}^{-1}\right)$ exceeded the normal range for fresh waters set by the DENR Administrative Order No. 34 Series of 1990 ( 0.05 to $\left.0.1 \mathrm{mg} \mathrm{L}^{-1}\right)$. Potential sources of phosphates may include fertilizers from adjacent agricultural farms, laundry soaps, animal manure, and quarrying activities observed in the area.

\section{CONCLUSION AND RECOMMENDATIONS}

Pagbanganan River supports a variety of planktonic algae that serve as primary producers in aquatic ecosystems. Out of the 20 pollution indicator genera reported by Palmer (1969), ten were recorded, and four of these were among the most abundant algae in the river. However, the abundance of some indicator genera was not that high during the sampling period, resulting in low pollution index scores. Based on Palmer's Pollution Index Scores, there is "less" organic pollution existing in the river. This could imply that water is still relatively safe for general household uses (eg, washing clothes, taking a bath). It is suggested that there should be continuous monitoring of the Pagbanganan River's water quality, and conservation measures should be implemented to preserve the river's health. For further research, other areas along the river's stretch can be assessed to determine the water quality of the other villages or barangays. Sampling duration could be extended to cover both dry and wet seasons to understand better the dynamics of these pollution indicator genera thriving in the river.

\section{REFERENCES}

Alvarado AC. 2005. Geomorphological characterization and discharge determination of the Pagbanganan River watershed (BS thesis). Leyte State University, Visca, Baybay, Leyte

Beaugrand G, Ibanez F \& Reid PC. 2000. Spatial, seasonal and long-term fluctuations of plankton in relation to hydroclimatic features in the English Channel, Celtic Sea and Bay of Biscay. Marine Ecology Progress Series 200:93-102

Belcher $\mathrm{H}$ and Swale E. 1979. An illustrated guide to river phytoplankton. Institute of Terrestrial Ecology, Culture Center of Algae and Protozoa, Cambridge

Bellinger EG and Sigee DC. 2010. Freshwater algae: Identification and use as bioindicators. John Wiley \& Sons, Lt

Department of Environment and Natural Resources (DENR) Administrative Order No. 34, Series of 1990. Revised water usage and classification/ Water quality criteria amending Section Nos. 68 and 69, Chapter III of the 1978 NPCC Rules and Regulations

Gadzała-Kopciuch R, Berecka B, Bartoszewicz J \& Buszewski B. 2004. Some considerations about bioindicators in environmental monitoring. Polish Journal of Environmental Studies 13(5):453-462 


\section{Planktonic algae as bioindicators of water quality in Pagbanganan River}

Galinato MI and Evangelio JC. 2016. Dynamics of Plankton Community in Banahaopalhi River in Leyte, Philippines. Annals of Tropical Research 38(2):130-152

Hassan AS, Okuofu CA \& Balogun JK. 2008. The use of biological index of pollution in assessing quality of rural water sources in Zaria, Nigeria. Science World Journal 3:2

Jose $L$ and Kumar C. 2011. Evaluation of pollution by Palmer's algal pollution index and physico-chemical analysis of water in four temple ponds of Mattancherry, Ernakulam, Kerala. Nature Environment and Pollution Technology 10(3):471-472

Karr JR, Allen JD \& Benke AC. 2000. River conservation in the United States and Canada. In Boon PJ, Davies BR \& Petts GE (eds) Global Perspectives on River Conservation: Science, Policy, and Practice (pp3-39). John Wiley \& Sons, Inc., New York

Kumari P, Dhadse S, Chaudhari PR \& Wate SR. 2007. A biomonitoring of plankton to assess quality of water in the lakes of Nagpur City. Proceedings of Taal 2007: the 12th World Lake Conference (pp160-164)

Labonite EK and Belonias BS. 2013. Community structure of planktonic algae in Pagbanganan River, Baybay City, Leyte. Science and Humanities Journal 10:5482

Lacdan NF, Javier LMV, Pagaddu JVA \& Su GLS. 2014. Assessing water quality of Dao River, Batangas using phytoplankton biomonitoring. International Journal of Current Science 12:98-102

Martinez KAS. 2018. Developing a river health index: A study in Ylang-Ylang River, Cavite, Philippines, In 4th International Research Conference on Higher Education, Social Sciences (pp774-788)

Palmer CM. 1969. A composite rating of algae tolerating organic pollution. Journal of Phycology 5(1):78-82

Palmer CM. 1977. Algae and water pollution: An illustrated manual on the identification, significance, and control of algae in water supplies and in polluted water. Municipal Environmental Research Laboratory, Office of Research and Development, US Environmental Protection Agency, Ohio

Salem Z, Ghobara M \& El Nahrawy AA. 2017. Spatio-temporal evaluation of the surface water quality in the middle Nile Delta using Palmer's algal pollution index. Egyptian Journal of Basic and Applied Sciences 4:219-226

Stevenson RJ and Pan Y. 1999. Assessing environmental conditions in rivers and streams using diatoms. In Stoermer EF and Smol JP (eds) The Diatoms: Applications for the Environmental and Earth Sciences (pp11-40). Cambridge University Press, Cambridge

Suthers I, Bowling L, Kobayashi T \& Rissik D. 2009. Sampling methods for plankton: In Suthers I \& Rissik D (eds) Plankton: A Guide to their Ecology and Monitoring for Water Quality (pp73-114), CSIRO Publishing, Collingwood, Vic., Australia

Verma JP. 2002. Ecology and ethology of aquatic biota. Volume 1. Edited by Kumar, A.A.P.H. Publishing Corporation, New Delhi 